\title{
АДМІНІСТРАТИВНА ДІЯЛЬНІСТЬ ПРАЦІВНИКІВ НАЦІОНАЛЬНОЇ ПОЛІЦІЇ ЩОДО ВИКОНАННЯ НОРМАТИВНИХ АКТІВ ПРО АДМІНІСТРАТИВНЕ СТЯГНЕННЯ ПІД ЧАС ПАНДЕМІЇ В УКРАЇНІ
}

Євчук Т. В., Заросило В. О., Заросило В. В.

у статmі розглядаються питання розвитку законодавства щодо адміністративної відповідальності осіб, які порушували і порушують карантинні обмеження і правила в Україні. Доведено, що як на законодавчому рівні, так і на рівні Кабінету Міністрів України припустилися помилок у введенні карантинних обмежень, що вплинуло на рівень дотримання карантину і на притягнення до адміністративної відповідальності осіб, які його порушували. Проаналізовано процес складання відповідних документів працівниками Національної поліціі, виділено основні недоліки в зазначеній діяльності. Доведено, що працівники Національної поліції допускали низку безвідповідальних дій, які призвели до уникнення відповідальності осіб, що вчинили правопорушення. Зазначені недоліки зафіксовано, запропоновано низку заходів, які 6 допомогли їх усуненню та недопущенню в майбутньому.

Ключові слова: пандемія, Національна поліція, законодавче забезпечення, порушення карантинних вимог, складання протоколів, удосконалення законодавства.

В статье рассматриваются вопросы развития законодательства об административной ответственности лиц, нарушавших и нарушающих карантинные ограничения и правила в Украине. Доказано, что как на законодательном уровне, так и на уровне Кабинета Министров Украины допущены ошибки при введении карантинных ограничений, что повлияло на уровень соблюдения карантина и на привлечение к административной ответственности лиц, допускавших его нарушения. Проанализирован процесс составления соответствующих документов работниками Национальной полиции, выделены основные недостатки в указанной деятельности. Доказано, что работники Наци ональной полиции допускали ряд безответственных действий, которые привели к избеганию ответственности лиц, допустивших правонарушения. Указанные недостатки зафиксированы, предложены меры, которые бы помогли их устранению и недопущению в будущем.

Ключевые слова: пандемия, Начиональная полиция, законодательное обеспечение, нарушение карантинных требований, составление протоколов, совершенствование законодательства.

Yevchuk T. V., Zarosylo V. O., Zarosylo V. V. Administrative activity of the National police officers on enforcement of normative legal acts of the administrative penalty during a pandemic in Ukraine

The current state of administrative activity of the National Police is quite difficult, because in the conditions of quarantine the issue of detection and prevention of offenses requires deep and comprehensive training of the National Police. The article considers the development of legislation on administrative

(с) Євчук Т. В., Заросило В. О., Заросило В. В., 2020 liability of persons who have violated and violate quarantine restrictions and rules in Ukraine.

It should be noted that legislation during the pandemic was quite active. This is due to the fact that for the first time in the world there is a problem that no state can solve. Therefore, changes to the legislation were quickly prepared and appropriate decisions were made.

It has been proved that both at the legislative level and at the level of the Cabinet of Ministers of Ukraine, a number of mistakes were made in the introduction of quarantine restrictions, which affected both the level of quarantine and administrative prosecution of violators. The process of drawing up the relevant documents by the National Police was analyzed and the main shortcomings in this activity were highlighted. It has been proven that the National Police officers committed a number of irresponsible actions, which led to the avoidance of those who committed offenses. Such actions include:

- lack of personal data of offenders in separate protocols, i.e. when drawing up protocols for offenders, National Police officers did not always establish the necessary data and did not require violators to present passports or other personal documents, although this was also enshrined in law;

- lack of descriptions of the nature of the offenses, which indicate that the National Police officers did not clearly study the new legislation and could not formulate appropriate descriptions of the offenses;

- lack of references to the relevant regulations, which were violated, which also indicate that the National Police officers who drew up the relevant protocols were not held targeted classes and instructional meetings and examples of reporting were not worked out.

These shortcomings in most cases were caused by the fact that the police worked in rather unusual conditions, and the Ministry of Internal Affairs of Ukraine and the relevant services did not prepare the necessary instructions to reduce the number of violations.

The article records most of the violations committed by the National Police and proposes a number of measures to help eliminate and prevent them in the future.

Key words: pandemic, National Police, legislative support, violation of quarantine requirements, drawing up protocols, improvement of legislation.

Постановка проблеми та їі актуальність. Пандемія змінила цілу низку вже сформульованих аспектів життя людей і здійснення правоохоронної діяльності. Верховна Рада України та Кабінет Міністрів України внесли досить багато змін до законів України й інших нормативних актів, які були спрямовані на протидію поширенню коронавірусної інфекції та збереження не тільки здоров'я, але й життя громадян України. Цими нормативними актами було передбачено посилення кримінальної і адміністративної відповідально- 
сті за порушення карантинних норм. Окремі аспекти застосування зазначених нормативних актів, особливо у сфері виконання покарань у вигляді адміністративних стягнень, не було врегульовано. Унаслідок таких дій велика кількість протоколів про адміністративні правопорушення у сфері недотримання вимог законодавства щодо карантинних норм не принесли відповідного ефекту, навпаки, показали, особливо по-різному висвітлені в засобах масової інформації, що карантинні обмеження можна порушувати.

Аналіз останніх досліджень і публікацій. Питання складання протоколів про порушення вимог карантинного законодавства практично не розглядалося в науковій літературі, адже практики й аналізу такої діяльності не проводилося. Окремі загальні питання щодо адміністративної діяльності правоохоронних органів розглядалися в роботах М.В. Завального [1] та деяких інших дослідників [2; 7]. Більш детально питання складання протоколів про адміністративні правопорушення розглядаються в навчальних посібниках з організації адміністративної діяльності працівників внутрішніх справ [3; 4; 5; 6]. Загальні питання складання адміністративних протоколів вивчено досить детально, але складання протоколів під час пандемії має свої особливості, тому їх необхідно проаналізувати. Крім того, необхідно провести аналіз нормативних актів, які дають можливість складати відповідні протоколи, що в подальшому можуть бути підставою для притягнення порушників до відповідальності.

Метою статті $\epsilon$ висвітлення окремих аспектів недоліків у законодавчому забезпеченні діяльності правоохоронних органів у сфері виконання вимог нормативних актів і у практичній діяльності поліцейських, які складали відповідні протоколи про порушення карантинних норм.

Виклад основного матеріалу. Питання про притягнення до адміністративної відповідальності за порушення карантинних вимог з'явилося після 11 березня 2020 р., тобто після ухвалення постанови Кабінету Міністрів України «Про запобігання поширенню на території України коронавірусу COVID-19» від 11 березня 2020 р. № 211 [8], відповідно до Закону України «Про захист населення від інфекційних хвороб» [9]. Антикоронавірусні заходи були конкретизовані вже в доповненні до зазначеної постанови і передбачали:

- із 17 березня заборону проведення всіх масових заходів, культурних, релігійних, розважальних, спортивних, соціальних та інших, але якщо вони проводяться, то в них не повинно брати участь понад 10 осіб;

- заборону діяльності закладів громадського харчування, торгівлі, закладів культури, крім продуктових магазинів і аптек;

- заборону перевезення населення будь-яким громадським транспортом, за винятком тих, хто працюють на об'єктах критичної інфраструктури, але також не більше 10 осіб, за спеціальними дозволами;

заборону перевезення пасажирів залізничним транспортом тощо [10].

Проте дані нормативні акти не могли реалізовуватися без відповідного законодавчого забезпечення. Законом України «Про внесення змін до деяких законодавчих актів України, спрямованих на запобігання виникненню i поширенню коронавірусної хвороби (COVID-19)» [9] було внесено зміни до Кодексу Укра- їни про адміністративні правопорушення i введено ст. 44-3 «Порушення правил щодо карантину людей» [10]. У цій статті визначено, що особи, які допускають «порушення правил щодо карантину людей, санітарно-гігієнічних, санітарно-протиепідемічних правил i норм, передбачених актами законодавства, а також рішень органів місцевого самоврядування 3 питань боротьби з інфекційними хворобами, притягаються до штрафу на громадян від однієї до двох тисяч неоподатковуваних мінімумів доходів громадян і на посадових осіб - від двох до десяти тисяч неоподатковуваних мінімумів доходів громадян» [10].

Одразу варто зазначити, що стаття не передбачає посилення відповідальності, якщо особа вдруге порушила вимоги карантинного законодавства, що деякою мірою $€$ приводом для повторних порушень.

Для визначення випадків порушення карантину та складання відповідних протоколів необхідно проаналізувати значення термінів «карантин людей», який згадано в наведеній статті, та «санітарно-протиепідемічні правила та норми», що також $\epsilon$ складовою частиною статті [10].

Термін «карантин» у законодавстві визначено як адміністративні та медико-санітарні заходи, які вводяться державними органами і застосовуються з метою попередження поширення особливо небезпечних інфекційних хвороб. Тобто це нормативно-правові акти, які ухвалюються центральними органами виконавчої влади. Вони встановлюються саме з метою дотримання вимог держави у сфері охорони здоров'я, а також запобігання поширенню інфекційних хвороб.

Як уже згадувалось, Кабінет Міністрів України спочатку встановив досить малі обмеження, проте в подальшому вони були замінені більш жорсткими, що загалом позитивно вплинуло на поширення інфекційної хвороби - коронавірусу.

Отже, питання відповідальності за порушення встановлених норм $\epsilon$ деякою мірою подвійним. Окремі обмеження запроваджено Кабінетом Міністрів України у згаданих постановах, але органи місцевого самоврядування можуть самі також запроваджувати окремі обмеження. Органи місцевого самоврядування можуть встановлювати більш жорсткі обмеження, ніж ті, які були встановлені Кабінетом Міністрів України.

Поліцейським, яких зобов'язано стежити за дотриманням згаданих обмежень та правил, тобто запобігати адміністративному порушенню, передбаченому у ст. 44-3 Кодексу України про адміністративні правопорушення, потрібно враховувати нормативні акти центральних органів влади і органів місцевого самоврядування. Не всі органи місцевого самоврядування ухвалювали відповідні нормативні акти.

Отже, питання про адміністративну відповідальність за адміністративне порушення, передбачене ст. 44-3 Кодексу України про адміністративні правопорушення, має передусім чітко відповідати ознакам складу адміністративного правопорушення, передбаченого згаданою статтею.

Оскільки у ст. 44-3 Кодексу України про адміністративні правопорушення не визначено конкретно, які законодавчі акти порушуються, то можна констатувати, що дана стаття $\epsilon$ відсилочною. Працівники правоохоронних органів, які повинні виявляти згадані правопорушення, мають чітко визначати, який нормативний акт порушено. 
Із цією метою, мабуть, було необхідно забезпечити працівників Національної поліції всіма нормативними актами, які передбачали покарання за їх порушення.

Якщо взяти конкретно, наприклад, порушення щодо кількості осіб, які має перевозити водій комунального транспортного засобу, тобто замість 10 осіб він перевозить 12, то логічно, що протоколи про дане правопорушення мають бути складеними як на водія, так і на двох зайвих пасажирів. Водночас з'ясувати, які ж пасажири були зайвими, не виявляється можливим.

Найбільш контраверсійним було обмеження щодо виходу на вулиці та в парки. Звичайно, міська влада, яка вводила такі обмеження, керувалася принципами убезпечення життя і здоров'я людей, проте громадяни мали виходити купувати продукти чи ліки, а вихід із дому міг розцінюватися як порушення і підстава для складання протоколу.

Водночас виникали досить неординарні ситуації, як-от складання протоколу на особу, яка плавала в річці Дніпро в місті Києві, а поряд нікого не було. Поліція склала протокол, який був направлений до суду, але порушник не був притягнутий до адміністративної відповідальності.

Варто зазначити, що один адміністративний протокол про фіксацію правопорушення, передбаченого ст. 44-3 Кодексу України про адміністративні правопорушення, в окремих судах не сприймався як доказ учиненого адміністративного правопорушення. Судді вимагали відеофіксації порушення, пояснень свідків. У такому разі також виникає правова колізія. Суддя має право вимагати перелічені вище докази, але якщо за умов карантину на вулиці немає можливості знайти свідків.

Отже, необхідно буде внести відповідні доповнення до законодавства для того, щоб судді не могли використовувати згадані підстави для відмови в ухваленні рішень.

Загалом, як показав аналіз питання щодо притягнення до відповідальності за порушення ст. 44-3 Кодексу України про адміністративні правопорушення, станом на 6 квітня 2020 р. [11] велика кількість протоколів, які були складені працівниками Національної поліції, були або повернені судами, або особи не понесли покарання.

Головними проблемами оформлення відповідних документів, як зазначено в наведеному аналізі, були такі: - ознаки адміністративного правопорушення, передбаченого ст. 44-3 Кодексу України про адміністративні правопорушення, обов'язково повинні містити посилання на конкретний нормативно-правовий акт, що встановив обмеження чи правила, яких не дотрималась особа, на яку складено відповідний адміністративний протокол;

- у матеріалах окремих справ немає даних щодо особи, яка вчинила правопорушення і має притягатися до адміністративної відповідальності.

- у деяких матеріалах нечітко визначена суть правопорушення, тобто не вказано, які саме дії вчинила особа під час порушення встановлених вимог карантину;

окремі особи, стосовно яких складено протоколи про порушення карантинних вимог, особливо у сфері торговельної діяльності, не були суб'єктами господарювання, наприклад, вони були лише продавцями, а не господарями торговельних підприємств; в окремих випадках протоколи складалися на осіб щодо продажу непродовольчих товарів в умовах магазинів, що здійснювали торгівлю продуктами харчування і засобами гігієни, зазначена торгівля не утворює складу правопорушення, передбаченого у ст. 44-3 Кодексу України про адміністративні правопорушення;

- окремі особи, які порушували карантинні вимоги, чинили опір законним вимогам працівників поліції, проте додаткових протоколів не складалося, а в судовому засіданні особи не визнавали себе винними, суд ухвалював рішення на їхню користь;

не завжди здійснювалася фото- та відеофіксація порушень, зазначені матеріали не додавалися до складених протоколів, що також давало можливість окремим особам уникати відповідальності за вчинені правопорушення;

не завжди використовувалися методи попередження осіб про порушення карантинних обмежень, роз'яснення необхідності їх дотримання.

Висновки. У підсумку можна зробити такі висновки:

1. Виникнення пандемії загалом не було неочікуваним, адже захворювання на коронавірус фіксувалися в Китайській Народній Республіці ще в листопаді 2019 р., проте ні керівництво країни, ні відповідні міністерства не вжили належних заходів, щоб убезпечити населення України від інфекційних захворювань.

2. У перші дні введення карантину не було відповідних роз'яснень та нормативних актів стосовно обмежень і заборон, лише через декілька днів вони були частково розроблені, проте чіткої системи їх застосування не має дотепер.

3. Не було швидкої реакції з боку законодавчих органів стосовно введення нових норм, які б удосконалювали карантинні обмеження. Відповідний Закон України був ухвалений лише 17 березня 2020 р., тоді як карантинні обмеження було введено із 12 березня. Отже, усі документи, які було складено до 17 березня, можна вважати порушеннями ст. 62 Конституції України.

4. Для поліцейських, які мали стежити за дотриманням вимог карантину, від самого початку не було розроблено вказівок, тому іноді виникали проблеми як зі складанням відповідних протоколів, так і з розглядом матеріалів у судових засіданнях.

5. Для вдосконалення роботи Національної поліції необхідно розробити пропозиції щодо уточнення підготовки матеріалів за адміністративні правопорушення для розгляду в судах, крім того, визначити чітко, які матеріали необхідно додатково готувати для розгляду в судовому засіданні, тому що суди часто використовують аспекти щодо відправлення матеріалів на доопрацювання як підставу для уникнення відповідальності особи, яка вчинила правопорушення, адже термін розгляду становить два місяці.

\section{Література}

1. Завальний М.В. Порушення справи про адміністративне правопорушення та їі розслідування. Університетські наукові записки. 2009 № 4 (32). С. 160-165.

2. Абдулкадірова Е.Е. Участь захисника під час розгляду справ про адміністративні правопорушення патрульною поліцією. Науковий вісник Національної академії внутрішніх справ. 2019 № 4 (113). С. 112-118.

3. Адміністративна діяльність : навчальний посібник / за заг. ред. О.І. Остапенка. Львів : ЛІВС, 2002. 252 с. 


\section{Правове забезпечення адміністративної реформи}

4. Адміністративна діяльність : навчальний посібник / М.В. Ковалів та ін. Київ : Правова єдність, 2009. 432 с.

5. Адміністративна діяльність органів внутрішніх справ : навчальний посібник / за заг. ред. Є.М. Мойсеєва. Київ, 2010. 428 с.

6. Адміністративна (поліцейська) діяльність органів внутрішніх справ. Спеціальна частина : підручник / за заг. ред. В.В. Коваленка, Ю.І. Римаренка, В.І. Олефіра. Тернопіль : Терно-граф, 2011. 528 с.

7. Опришко І.В. Національна поліція України як суб'єкт реалізації державної політики у сфері внутрішніх справ. Наука і правоохорона. 2018. № 3. С. 90-99.

8. Про запобігання поширенню на території України коронавірусу COVID-19 : постанова Кабінету Міністрів України від 11 березня 2020 р. № 211. URL: https://www.kmu.gov.ua/npas/pro-zapobigannya-poshim 110320rennyu-na-teritoriyi-ukrayini-koronavirusu-covid-19.

9. Про внесення змін до деяких законодавчих актів України, спрямованих на запобігання виникненню і поширенню коронавірусної хвороби (COVID-19) : Закон України. Відомості Верховної Ради України. 2020. № 16. Ст. 100.

10. Кодекс України про адміністративні правопорушення. Відомості Верховної Ради Української Радянської Соціалістичної Республіки. 1984. Дод. до № 51. Ст. 1122.

11. Аналіз постанов по 44-3 КУпАП. URL: https:// docs.google.com/document/d/10WAKFmcTJsQMWvQJ6fPWw y53awkTSXkncg8SwM6Ujbw/mobilebasic.

Євчук T. В., кандидат юридичних наук, доцент кафедри правових дисциплін Одеського інституту Міжрегіональної академії управління персоналом

Заросило В. О., доктор юридичних наук, професор, завідувач кафедри правоохоронної та антикорупційної діяльності

Навчально-наукового інституту права імені Володимира Великого Міжрегіональної академії управління персоналом

Заросило В. В., кандидат юридичних наук, викладач вищої категорії

Київського державного коледжу готельного господарства 